\title{
Ingen spøk å gå på trygd
}

\section{Det er ofte krevende for brukere med psykiske problemer å forholde seg til trygdesystemet.}

E ter å ha arbeidet $\mathrm{i}$ helsevesenet hele mitt yrkesaktive liv har jeg erfart at vi fagfolk, enten vi sitter i behandlingssektoren eller i Nav, har lett for å glemme at hver og enkelt av oss ikke ser hele bildet og derfor kan komme til å trekke feil konklusjoner på vegne av brukerne våre. Dette kan skape misforståelser og feilslutninger i behandlingsforløpet og utrygghet og mistillit til systemet hos brukerne. Derfor er det viktig at vi kommuniserer på tvers av sektorer, at vi legger frem våre synspunkter, lytter til hverandre og kommer frem til best mulige løsninger i fellesskap, til beste for brukerne.

\begin{abstract}
Kari
«Kari 19 år» henvises til psykiatrisk poliklinikk. Hun har droppet ut av skolen, har problemer på jobb, og føler seg ofte misforstått. Fastlegen har henvist henne til poliklinikken med mistanke om at hun har en bipolar sykdom. Hun har hatt tendens til manier og er nå deprimert. «Kari» er nesten ferdig utdannet frisør. Hun mestret teorien på skolen, men fikk problemer da hun kom ut i praksis og skulle ha kundekontakt. Stemningsmessig svinger hun en del, og tilbakemeldingen fra praksisfeltet var at hun var for ustabil til å arbeide der. I tillegg til utredning og behandling i poliklinikken har vi brukt mye tid på viktige samarbeidspartnere; Nav, mulige arbeidsgivere og skolen. Det har vært en lang prosess. Noe av det vanskeligste, slik jeg ser det, har vært å hjelpe «Kari» til å bli forstått, særlig i Nav-systemet.
\end{abstract}

For noen år siden deltok jeg på en rekke medi-

\section{Hovedbudskap}

Artikkelforfatteren hevder tverrfaglig samarbeid mellom sektorene er nødvendig for å hjelpe brukere av psykisk helsevern og Nav best mulig.

\section{Søkeord}

Les mer og finn litteraturhenvisninger på våre nettsider.

) Psykisk lidelse, Samarbeid

, Kommunikasjon , Tverrfaglighet sinsk-etiske seminarer. Jeg måtte stadig erkjenne at andre hadde en helt annen oppfatning av en sak enn meg. De andre deltakerne var også helsearbeidere, og jeg hadde forventet at vi hadde de samme grunnverdiene og stort sett skulle være enige i flere av vurderingene. Det viste seg ikke å være tilfellet. Det ble store diskusjoner og mange motsetninger oppsto. Noen virket som de oppfattet uenighetene som personangrep. Sakene vi drøftet var svært alvorlige, og de ulike synene kunne fått store konsekvenser for pasientene så vel som for deres familier. Dette lærte meg at vi må være bevisste på at våre samarbeidspartnere har ulike utgangspunkt og ulike syn - selv om vi er kolleger. Derfor må vi som arbeider med mennesker alltid bestrebe oss for å belyse en situasjon fra alle sider og lytte til flest mulig stemmer. Det kan ofte være vanskelig å etterspørre de andre samarbeidspartnernes mening uten at det blir oppfattet som kritikk. Men uten åpenhet fra alle sider kan de gode prosessene vi ønsker oss bli vanskelige å fă til.

\section{Interessert nysgjerrighet}

Psykiatriske pasienter sliter ofte med lav selvfølelse, kanskje psykoser, depresjoner og forskjellige typer angst. «Karis» symptomer svinger, fra at hun til tider klarer seg nesten uten bistand til at hun $\mathrm{i}$ perioder har behov for mye omsorg, hjelp og støtte. I enkelte perioder har hun svært vanskelig for å få sagt ifra. Da trenger hun interessert nysgjerrighet fra hjelpere som etterspør hva hun tenker og trenger hjelp med. I disse periodene må man ofte gi praktisk hjelp, noen ganger ta helt over, eller gjøre ting sammen med henne.

\section{Frykt for systemet}

For «Kari» er Nav-systemet spesielt utfordrende. Hun tør ikke lage avtaler med andre instanser av frykt for ikke å få sendt meldekortene på riktig dato, og tør ikke gå ut av frykt for at Nav skal ringe, eller at det skal komme brev om at hun må møte opp på kort varsel. Hun vet at krysser hun av feil på meldekort eller -skjema kan det få store konsekvenser. Hun kan miste inntekt, og må kontakte alle instanser hun har økonomiske avtaler med. I tillegg må hun mest sannsynlig også ha nødhjelp til mat. Overgangen fra sykmelding til arbeidsav- klaring er en situasjon som kan føre til en periode uten inntekt - dersom personen ikke får denne praktiske hjelpen.

Dette mener jeg Nav kan gjøre noe med. Det er ofte enkle ting som svikter. Først og fremst må saksbehandler ta seg tid til å etablere en trygg kontakt - det kan skje ved å gå gjennom meldekort eller -skjema, vise hvordan de skal fylles ut, sjekke ut om brukeren forstår informasjonen og er i stand til å fylle ut selv, eller tilby å gjøre det sammen med brukeren. En bruker som forstår hva han eller hun skal gjøre vil være mer motivert til å følge opp selv. Ikke minst er det viktig å sørge for at bruker får ny timeavtale, et timeavtalekort med navn og direktenummer til saksbehandler. Den enkelte saksbehandler må også ha oversikt over Navs ulike virkemidler - «Ny GIV», kompetanseprogram, ungdomsteam, arbeidsgiverlos og så videre.

\section{Manglende åpenhet}

Først når det grunnleggende er på plass og tryggheten mellom saksbehandler og bruker er etablert, kan situasjonen belyses fra flere sider i samarbeidsmøtet. I praksis kan det ofte virke som den enkelte møtedeltaker stiller med sin agenda og er mest opptatt av å få frem sin egen oppfatning. Egentlig har vi et felles mål - å hjelpe personen videre. Men for å komme frem til riktige konklusjon må alle synspunkter legges fram og saken belyses fra flere sider. Hvis dette ikke skjer, kan konklusjoner bli trukket på ufullstendig grunnlag. Det er i så fall alvorlig. Pasienten kan lett få inntrykk av at det eneste budskapet er: «Gå på jobb!» Noen kan føle seg krenket eller bli sinte, dialogen i møtet forringes, og konklusjonen kan til og med bli feil. Og like alvorlig; det tar lengre tid å bygge opp motivasjon og trygghet på nytt.

For «Kari» ble dette en lang prosess. Hun er bare ett eksempel blant mange på hvor viktig det er at vi lytter til hverandre. Utfordringen er å stille spørsmål og gi uttrykk for synspunkter på en slik måte at kolleger ikke behøver å gå i forsvar, men heller åpne opp for nye sider av en sak. Dialogen er nøkkelen. Måten vi som fagfolk kommuniserer på, og som igjen kan få konsekvenser for pasientene, er for meg et stadig tilbakevendende dilemma. III 